Key Biodiversity Area Special Series

\title{
Identifying Important Plants Areas (Key Biodiversity Areas for Plants) in northern Algeria
}

\author{
N. Yahi ${ }^{1}$, E. Vela ${ }^{2}$, S. Benhouhou ${ }^{3}$, G. De Belair ${ }^{4}$ \& R. Gharzouli ${ }^{5}$ \\ 1 Université des Sciences et de la Technologie Houari Boumediene, USTHB, Faculté des Sciences Biologiques. BP 32 El Alia, \\ 16111, Bab Ezzouar, Algérie \\ ${ }^{2}$ Université Montpellier-2, UMR AMAP (botAnique et bioinforMatique de l'Architecture des Plantes), TAA-51/PS2, Bd de la Lironde, \\ Montferrier-le-Lez, 34398 Montpellier cedex 5, France \\ ${ }^{3}$ Ecole Nationale Supérieure Agronomique, Hassen Badi, 16200, El Harrach, Algeria \\ ${ }^{4}$ Université "Badji Mokhtar", B.P. 533, 23000 Annaba, Algérie \\ ${ }^{5}$ Université Ferhat ABBAS, Faculté des Sciences de la Nature et de la Vie Campus EL BEZ 19000 Sétif, Algérie \\ Email: ${ }^{1}$ nyahi@hotmail.fr (corresponding author), ${ }^{2}$ errol.vela@cirad.fr, ${ }^{3}$ sbenhouhou@yahoo.fr, ${ }^{4}$ debelairg@yahoo.com, \\ ${ }^{5}$ gharzoulir2002@yahoo.fr
}

Date of publication (online): 06 August 2012 Date of publication (print): 06 August 2012 ISSN $0974-7907$ (online) | 0974-7893 (print)

\section{Manuscript details:}

Ms \# 02998

Received 08 November 2011

Final revised received 20 January 2012

Finally accepted 01 June 2012

Citation: Yahi, N., E. Vela, S. Benhouhou, G De Belair \& R. Gharzouli (2012). Identifying Important Plants Areas (Key Biodiversity Areas for Plants) in northern Algeria. Journal of Threatened Taxa 4(8): 2753-2765.

Copyright: (c) N. Yahi, E. Vela, S. Benhouhou G. De Belair \& R. Gharzouli 2012. Creative Commons Attribution 3.0 Unported License. JoTT allows unrestricted use of this article in any medium for non-profit purposes, reproduction and distribution by providing adequate credit to the authors and the source of publication.

For Author Details and Author Contribution see end of this article.

Acknowledgements: The authors wish to express their gratitude to Elizabeth Radford and Bertrand Montmollin for their encouragement and guidance in writing this paper.
Abstract: A study was undertaken in 2010 to identify Important Plant Areas (Key Biodiversity Areas for Plants) in the south and east Mediterranean region, in order to prioritise the best sites for plant conservation action. It follows a first work of identification of Important Plant Areas (IPAs) initiated for Algeria and relates exclusively to the flora of northern Algeria. These IPAs were delineated in northern Algeria for those sites harbouring a number of "IPA selection species" (threatened species and locally endemic or restricted range). Recent taxonomic revisions estimate the number of national endemics for the north of Algeria (excluding the Sahara) to be over 300 taxa. In the present study, data were extracted from the global list of 22 IPAs identified for the north of Algeria. The species considered are i) threatened species as defined by the 1997 IUCN global red list of plants, ii) locally endemic species, iii) nationally threatened species. Trigger species, identified by combining the criteria of endemism and rarity, are mainly Algerian national endemics but also include some AlgerianMoroccan and Algerian-Tunisian endemics. One hundred and fifty two (152) trigger species were identified and these species, which have high ecological value, can be used to characterize the particular floristic interest of a site and can therefore be a useful tool for conservation purposes. Important gaps in knowledge have been highlighted, in particular those relating to taxonomy and the lack of up-to-date field data. It is therefore essential to undertake in situ research in order to better understand the distribution and status of these species. A flexible approach to identifying and recognising priority sites for plants using surrogate criteria, supplemented by expert opinion, alongside existing globally standardised criteria, is therefore essential if the most important sites for plant diversity are to receive the conservation attention they deserve.

Keywords: Endemic species, IPA, North Algeria, trigger species.

French Abstract and Keywords: See end of text
The Key Biodiversity Area series documents the application of the concept and showcases the results from various parts of the world. The series is edited under the auspices of the IUCN World Commission on Protected Areas/Species Survival Commission Joint Task Force on 'Biodiversity and Protected Areas', with the editors supported by BirdLife International, Conservation International, IUCN, National Fish \& Wildlife Foundation, NatureServe, Parks Canada, and Plantlife International.

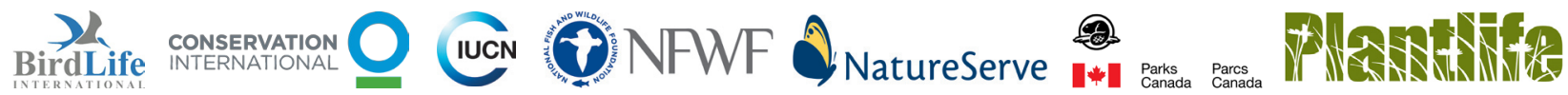




\section{INTRODUCTION}

In 2010 a study was undertaken to identify important plant areas (IPA -- key biodiversity areas for plants) in the south and east Mediterranean region, in order to prioritise the best sites for plant conservation action (Radford et al. 2011). This paper explains in detail how identification of these sites was undertaken in Algeria. It is a country with typical south and east Mediterranean biodiversity, with a huge number of local endemics. Knowledge on these species is partially documented and there is little data on the threat status of plant species. This study follows the work of identification of important plant areas (IPAs) initiated for Algeria by Yahi et al. (2011). It relates exclusively to the flora of northern Algeria (Mediterranean part), a region of $475,000 \mathrm{~km}^{2}$.

The Mediterranean basin has long been recognised as a global Biodiversity Hotspot (Médail \& Quézel 1997) due to the size and diversity of its flora; $10 \%$ of the world's vascular plants occur on $1.6 \%$ of the land surface. Ten smaller hotspots of floristic biodiversity within the basin have also been identified (Médail \& Quézel 1997; Véla \& Benhouhou 2007), two of which overlap with Algerian territory: the BeticoRifian complex in Algeria, Morocco and Spain and the Kabylies-Numidia-Kroumiria complex in Algeria and Tunisia. The latter has recently been identified as a centre of endemism and refuge area for species at the geographical limit of their distribution (Véla \& Benhouhou 2007; Médail \& Diadéma 2009). These regions are of immense importance for conservation but are too large scale for focused site-based conservation actions.

The north of Algeria (excluding the Sahara) holds 224 known nationally endemic taxa and approximately 1,630 rare taxa (Quézel \& Santa 1962-1963; Véla $\&$ Benhouhou 2007). However, following recent taxonomic revisions the estimate of the number of national endemics is now placed at over 300 taxa and the total number of taxa of elementary rank (species or subspecies) is 4,000 (Dobignard \& Chatelain 2010 2011), up from the previous count of 3,700 (Quézel \& Santa 1962-1963). This high biogeographical endemism is shared with bordering countries; thus Morocco to the west has 124 Algerian-Moroccan endemic taxa and Tunisia in the east has 58 AlgerianTunisian endemic taxa (Véla \& Benhouhou 2007).
This local endemism, associated with high habitat diversity, is a result of the Mediterranean climate, in turn influenced by altitude, large thermal amplitudes and a west-east rainfall gradient, combined with considerable topographic, geomorphological and geological diversity (Seltzer 1946; Emberger 1955).

The IPA (Anderson 2002; Plantlife International 2004) attempted to identify site-scale priority areas for conservation, using standard criteria that in part, corresponded to those used for identifying key biodiversity areas (Langhammer et al. 2007).

\section{METHODS}

Important plant areas in northern Algeria were identified using a combination of IPA criteria (Anderson 2002; Plantlife International 2004) and Important Forest Area criteria (Regato 2001), which were modified to reflect the data available for plant species in North African countries (Yahi et al. 2011; IUCN, Plantlife, WWF 2010 unpublished workshop report). IPAs in northern Algeria were delineated for those sites harbouring a number of "IPA selection species" (threatened species and locally endemic or restricted range). In terms of IPA criteria (Plantlife International 2004), these IPA selection species allowed application of criterion A (presence of globally, regionally and/or nationally endemic threatened species) and partial application of criterion B (species richness), by selecting the richest sites for locally endemic (restricted range) species. Sites selected using richness were not selected by habitat type (as required by full application of criterion B), as such data is not available in Algeria. There are no threatened habitat classifications for northern Algeria so IPA criterion C, for such habitats, could not be applied effectively. It is beyond the scope of the current project to delineate IPAs everywhere that restricted-range species occur in Algeria because there are so many such species in northern Algeria alone.

These criteria broadly relate to the KBA criteria for vulnerability and irreplaceability, although for one of the latter subcriteria, the threshold of $50,000 \mathrm{~km}^{2}$ used to define restricted range for animal taxa (Langhammer et al. 2007) is too large to apply to plant species, particularly in hotspot regions, because it would result in much of the northern part of the country being 
delineated as KBAs.

In the present study, data were extracted from the global list of the 21 IPAs identified for the north of Algeria (Yahi et al. 2011) and a new site added (the Collo Peninsula) using data collated subsequently. The taxa listed for each site are derived from literature sources (Battandier 1888-1890, Battandier \& Trabut 1895, Quézel \& Santa 1962-1963) and/or from personal data obtained during field observation. Taxonomic sources are the flora of Quézel \& Santa (1962-1963) and the synonymic index of Dobignard \& Chatelain (2010-2011). The species considered are:

(i) threatened species, as defined by the 1997 IUCN global red list of plants (Walter \& Gillett 1998) and the 2010 IUCN Mediterranean Red List of Freshwater Plants (Garcia et al. 2010); we do not include species listed "Rare", "Near Threatened", or
"Data Deficient";

(ii) locally endemic (restricted-range) species, defined as those with distributions of greater than $100 \mathrm{~km}^{2}$ but less than or equal to $5,000 \mathrm{~km}^{2}$, called restricted range endemic species, and those with a distribution less than or equal to $100 \mathrm{~km}^{2}$, called siterestricted endemic species - these two categories are mutually exclusive (IUCN et al. 2010);

(iii) nationally threatened species defined as rare, according to the criteria of rarity given in the Algerian flora (Quézel \& Santa 1962-1963).

In this study, we combine the criteria of endemism and rarity to identify what we call "trigger species". Trigger species for Key Biodiversity Areas are all those species that 'trigger' either the vulnerability and or the irreplaceablility criteria and thus 'trigger' sites as a KBA (Langhammer 2007). These were selected from

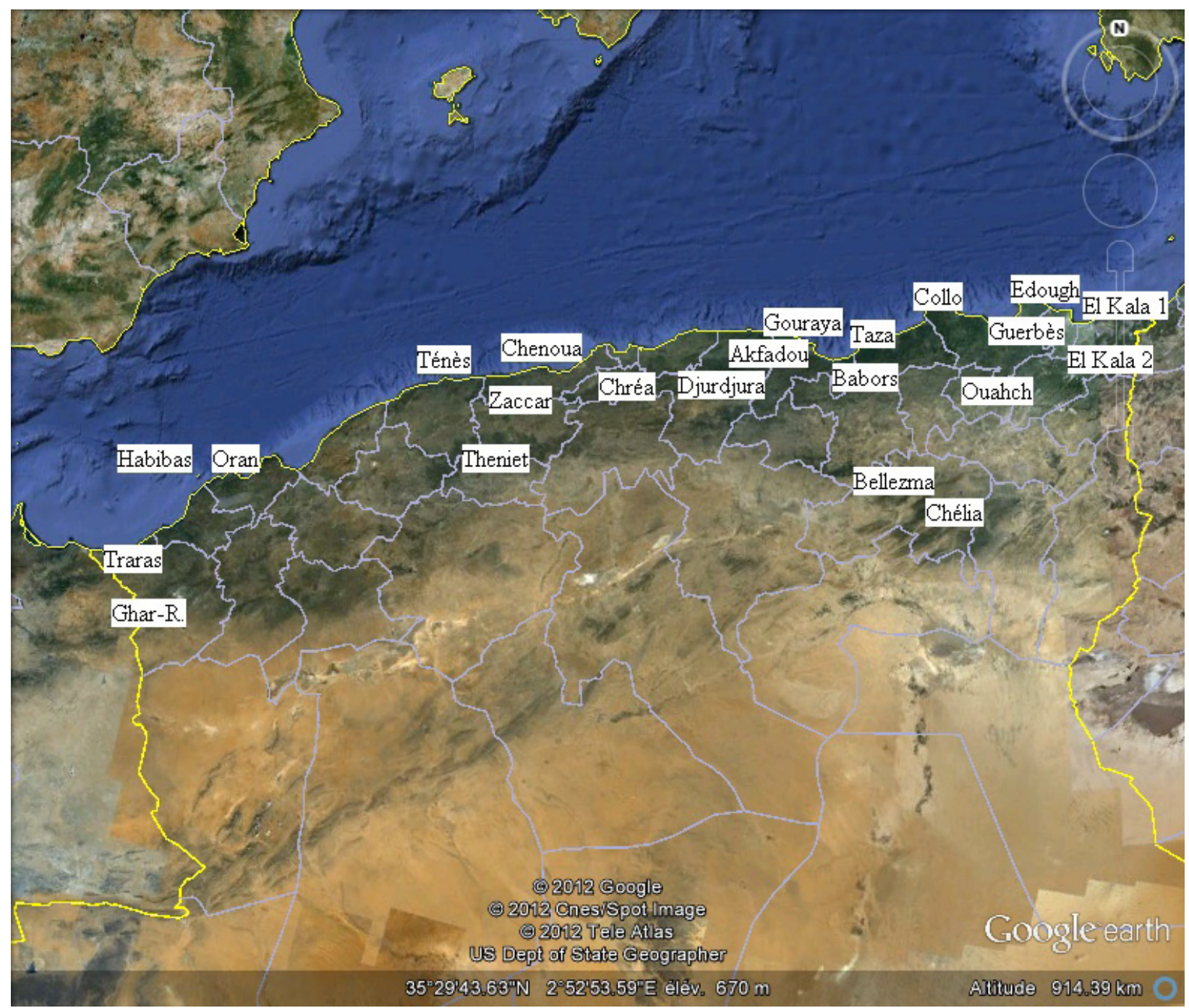

Image 1. Localisation of the 22 IPAs identified for the North of Algeria. 
the global IPA lists and are mainly Algerian national endemics but also include some Algerian-Moroccan and Algerian-Tunisian endemics, for those present in IPAs near the respective national borders. Their high ecological value can be used to characterize the particular floristic interest of a site and can therefore be a useful tool for conservation purposes.

\section{RESULTS}

Twenty two IPAs are identified in northern Algeria. These were identified within the phytogeographical sectors of the Oran region, the Algiers region, the Kabylies and Numidia, the Constantine mounts, the High Plains and the Saharan Atlas (Quézel \& Santa 1962-1963). The sites selected represent a range of habitats from the coasts to the mountains, encompassing wetlands, hills and plains. They extend from the wetland complex in El Kala in eastern Algeria to the montane forest of Ghar-Rouban in the westernmost area of the country (Image 1). They cover a total of $10,656 \mathrm{~km}^{2}$, comprising approximately $2.5 \%$ of Algeria's Mediterranean region. Of the 22 sites, $7(31 \%)$ are already benefitting from protectedarea status as national parks. A number of additional sites have been proposed as IPAs but further field investigations in these areas must be undertaken before these can be confirmed. These sites include Djebels Ksours and Krouz, Djebel Aïssa (recently classified as national park) and Djebel Amour, located in the Saharan Atlas.

Using the species lists established for the 22 IPAs, it is possible to make a first analysis linking these IPAs with KBA criteria (Table 1).

Regarding the vulnerability KBA criterion, results show that Critically Endangered species are present in two IPAs: El Kala 1 and El Kala 2. Endangered species occur in seven IPAs: El Kala 1, El Kala 2, Djebel Chelia, Babor, Taza, Gouraya and Oran's hills. Vulnerable species are present in 12 IPAs: El Kala 1, El Kala 2, Edough peninsula, Djebel Chelia, Babor, Taza, Akfadou, Gouraya, Djurdjura, Orans' hills, Ghar Rouban and Habiba's Islands. All the 22 IPAs contain nationally threatened species, restricted-range species and site-restricted species and so correspond to the KBA irreplaceability criteria.

The 587 species correspond to the total number of nationally threatened species extracted from the 22 IPAs list. It includes 153 trigger species and 434 nationally rare species. Among this total, there are two Critically Endangered, 11 Endangered and 10 Vulnerable species, a total of 23 species from the IUCN 1997 and 2010 red lists (Appendix 3). With regards to the irreplaceability criterion, 74 restricted-range species and 78 site-restricted species were identified (Appendices 1 and 2), including, respectively, 70 and 62 species not currently listed as threatened. Twenty of the species that qualify under the vulnerability criterion therefore, also qualify under the irreplaceability criterion; 16 are site-restricted and four are restricted range. For further details see Appendix 3.

In Table 2, for each of the 22 IPAs, we list the numbers of nationally rare species (Quézel \& Santa 1962-1963), of species listed as threatened (Critically Endangered, Endangered and Vulnerable) on IUCN Red Lists (Walter \& Gillett 1998; Garcia et al. 2010), and of restricted-range endemic and site-restricted endemic species. We also note whether each IPA has also been identified as a key biodiversity area for the presence of animal trigger species, in addition to plants (CEPF 2010).

Of the $152 \mathrm{KBA}$ trigger species, 94 occur at only one IPA, while 34 trigger species occur in two IPAs, 12 in three IPAs, three in four IPAs, and one in five IPAs (Appendix 4).

Table 1. Numbers of IPAs triggered by KBA criteria and number of species triggering KBA criteria

\begin{tabular}{|l|c|c|c|c|c|c|c|}
\hline & \multicolumn{4}{|c|}{ Vulnerability (KBA criterion) } & \multicolumn{2}{|c|}{$\begin{array}{c}\text { Irreplaceability (KBA criterion) } \\
\text { (N) }\end{array}$} & $\begin{array}{c}\text { Nationally rare species } \\
\text { (that do not qualify } \\
\text { under the other criteria) }\end{array}$ \\
\hline & CR & EN & VU & $\begin{array}{c}\text { Total IUCN 1997 \& } \\
2010 \text { Plant Red list }\end{array}$ & $\begin{array}{c}\text { Restricted-range } \\
\text { species }\left(<5,000 \mathrm{~km}^{2}\right)\end{array}$ & $\begin{array}{c}\text { Site-restricted species } \\
\left(<100 \mathrm{~km}^{2}\right)\end{array}$ & \\
\hline $\begin{array}{l}\text { Number of } \\
\text { IPAs }(\%)\end{array}$ & $2(9 \%)$ & $\begin{array}{c}7 \\
(31 \%)\end{array}$ & $\begin{array}{c}12 \\
(54 \%)\end{array}$ & $12(54 \%)$ & $22(100 \%)$ & $22(100 \%)$ & $22(100 \%)$ \\
\hline Plants & 2 & 11 & 10 & 23 & 70 & 62 & 434 \\
\hline
\end{tabular}


Table 2. Nationally rare species, IUCN Red List species, restricted-range species and restricted site species per IPA, and presence of animal as well as plant trigger species.

\begin{tabular}{|c|c|c|c|c|c|}
\hline IPAs & $\begin{array}{l}\text { Nationally rare } \\
\text { species }\end{array}$ & $\begin{array}{c}\text { IUCN Red List } 1997 \\
\text { \& } 2010 \\
\text { (CR/EN/VU only) }\end{array}$ & $\begin{array}{c}\text { Restricted-range } \\
\text { endemics } \\
<5000 \mathrm{~km}^{2}\end{array}$ & $\begin{array}{l}\text { Site-restricted } \\
\text { endemics } \\
<100 \mathrm{~km}^{2}\end{array}$ & $\begin{array}{c}\text { Also a Key } \\
\text { Biodiversity Area } \\
\text { for animal taxa }\end{array}$ \\
\hline El Kala 1 & 96 & 7 & 9 & 11 & $\sqrt{ }$ \\
\hline EI Kala 2 & 31 & 4 & 6 & 8 & $\sqrt{ }$ partial \\
\hline Edough peninsula & 36 & 1 & 6 & 3 & $\sqrt{ }$ \\
\hline Guerbes & 44 & 2 & 3 & 4 & $\sqrt{ }$ \\
\hline Collo peninsula & 14 & 1 & 4 & 1 & $\sqrt{ }$ \\
\hline Belezma & 43 & 3 & 4 & 3 & $\sqrt{ }$ \\
\hline Djebel Chelia & 42 & 2 & 6 & 7 & \\
\hline Djebel Ouahch & 23 & 1 & 4 & 5 & $\sqrt{ }$ partial \\
\hline Babor & 49 & 5 & 13 & 5 & $\sqrt{ }$ \\
\hline Taza & 42 & 4 & 7 & 6 & $\sqrt{ }$ \\
\hline Gouraya & 16 & 2 & 2 & 7 & $\sqrt{ }$ \\
\hline Akfadou & 39 & 1 & 13 & 2 & $\sqrt{ }$ \\
\hline Djurdjura & 89 & 1 & 20 & 6 & $\sqrt{ }$ \\
\hline Chréa & 65 & 0 & 9 & - & $\sqrt{ }$ \\
\hline Mont Chenoua & 17 & 0 & 1 & 1 & \\
\hline Cap Ténès & 10 & 0 & - & 4 & \\
\hline Theniet EI Had & 30 & 0 & 6 & 1 & $\sqrt{ }$ \\
\hline Zaccar & 24 & 0 & 4 & 2 & \\
\hline Oran Hills & 37 & 3 & 2 & 5 & \\
\hline Habibas Islands & 10 & 1 & - & 4 & $\sqrt{ }$ \\
\hline Traras Mountains & 22 & 0 & 5 & 5 & \\
\hline Ghar Rouban & 42 & 1 & 7 & 4 & \\
\hline
\end{tabular}

From a total of 152 endemic species ( 74 restrictedrange endemics and 78 site-restricted endemics), 20 are considered threatened and a further 41 considered "Rare", "Near Threatened", or "Data Deficient" according to the 1997 IUCN Red List or Garcia et al. (2010). Of these, 20 show a high threat level (Critically Endangered, Endangered, or Vulnerable). The remaining restricted-range and site-restricted endemic species are either legally protected at the national level (Décret exécutif $n^{\circ}$ 93-285 du 9 Joumada Ethania 1414 correspondant au 23 novembre 1993 fixant la liste des espèces végétales non cultivées protégées. JORA N ${ }^{\circ} 78$ du 28-11-1993. Page 7) but have not had their threat status formally assessed or they have no protection status despite their very limited distribution. Examples include Erica numidica, Genista aspalathoides, Odontites reboudii, O. ciliata (El Kala 1 et 2), Ophrys pectus (Edough peninsula, Djebel Ouahch), Matthiola “ numidica” (Edough peninsula), Hieracium peyrimhoffi, Chrysanthemum reboudianum
(Djebel Chelia), Adenocarpus "barbarus", Hieracium ernestii (Babor), Saxifraga baborensis, (Taza), Genista salditana, Pancratium "saldense" (Gouraya), Genista filiramea, G. vepres, Isoetes perralderiana, Silene choulettii (El Kala 2, Akfadou), Deckera racemosa (Taza, Djurdjura), Saxifraga "integrifolia" (Cap Ténès), Cephalaria mauretanica, Genista sarotes, Orchis "teschneriana", (Zaccar), Teucrium maghrebianum (Oran Hills), Hammatolobium kremerianum, Limonium asparagoides, Orobanche leptantha (Monts Traras), Eruca setulosa, Filago pomelii, Galium bourganeaum and Linaria burceziana (Ghar Rouban).

In Algeria the large number of species associated with the irreplaceably (restricted range) makes the possibility of an extremely long list of trigger species (and corresponding long list of sites). Conversely, the lack of IUCN threat status information, mean species hitting the vulnerability criteria are probably underrepresented. Overcoming this data deficiency, a list 
of 'selected' trigger species that highlight the most threatened and restricted species are chosen to designate as Important Plant Areas - or Key Biodiversity Areas for Plants. Selected trigger species present in only one IPA are shown in bold.

These selected trigger species are mainly "SRE" species with a few "RRE" species. The complete list being given in Appendix 4. The total of 86 selected trigger species includes 13 common to two or more IPAs. Twenty IPAs contain trigger species that only exist at one site. Many of these species are considered highly threatened and may be Alliance of Zero Extinction sites (sites containing the only remaining population of Critically Endangered species as defined using IUCN criteria) (Ricketts et al. 2005). However, lack of precise data for IUCN species assessments prevents us being able to confirm this.

\section{DISCUSSION}

Over $50 \%$ of the (total) IPAs identified for northern Algeria are located within the two regions in the Maghreb described as plant diversity hotpots by Véla \& Benhouhou (2007): 11 are in the KabyliesNumidia-Kroumiria hotspot and three in the BeticoRifean hotspot. However, eight IPAs have been identified outside of those areas. Of the 22 IPAs in northern Algeria, 17 IPAs are found within the priority corridor "Mountains, Plateaus, and Wetlands of the Algerian Tell and Tunisia" while the remaining five fall within the "Oranie and Moulouya" corridor (CEPF 2010). Fifteen Algerian IPAs (68\%) overlap with Key Biodiversity Areas identified using animal taxa, of which there are a total of thirty eight in the region - this overlap is greater than what was identified for other south and east Mediterranean countries within the CEPF analysis (Radford et al. 2011).

The identification of priority sites for plant conservation in Algeria, which has brought together significant amounts of existing data in a site-based format, will serve to increase the profile of northern Algeria's priority sites for plants, and to target investment in their conservation. However, the desire to ensure these sites meet global selection criteria does present a number of challenges, which indeed are common to all countries in the south and east Mediterranean. These challenges begin with the sheer number of plant species that are important to conservation and extend to the often difficult and incomplete taxonomies, a chronic lack of current data on species (and habitat) distributions and the extremely limited number of formal species status assessments (and associated Red Lists).

Only 79 taxa from the approximately 4,000 present in Algeria have been assessed using the latest IUCN criteria - under $2 \%$ of the flora. Twenty three of these species are classified as threatened (and therefore available for use under the KBA vulnerability criterion). This total is undoubtedly a fraction of the true number for a country which hosts 407 endemic or nearendemic species (Véla \& Benhouhou 2007), of which at least 78 have distributions of less than $100 \mathrm{~km}^{2}$ and a further 74 have distributions of less than $5,000 \mathrm{~km}^{2}$. Species assessed as threatened on the IUCN Red List are mainly endemic. Some non-endemic taxa, such as Senecio linifolius, which we suspect to be Endangered and is found at only one site in Algeria (Oran Hills), does not have any kind of formal conservation status. It is thus essential to undertake in situ research in order to understand the distributions of both endemic and non-endemic plant species and their conservation status. It is important also to recognise that the 1997 Red List data are old and incomplete. A more recent Red List is available but only for freshwater plants (Garcia et al. 2010).

In Algeria, the flora of Quézel \& Santa (1962-63), is the only valid national taxonomic reference, and is insufficient to (i) solve the many questions related to taxonomy, and (ii) give precise distributions of the species. It should be noted that the distributions of some restricted-range species were taken from those described by Quézel \& Santa 1962-63, and may be out of date now due to potential changes in the range of species therein and data collected subsequently. It should also be noted that several species not mentioned by these authors had already been described by Maire (1952-1987) adding to the potential complexity of the national taxonomic picture for plants. Recent field investigations by the authors of this paper (De Belair \& Boussouak 2002; De Belair et al. 2005; De Belair \&Véla 2011; Véla et al. 2012, and unpubl. pers. obs. and collaborators (Ouarmim \& Dubset 2008; Medjahdi et al. 2009) resulted in several new or rediscovered species records for Algeria: Brassica "numidica" (Edough peninsula), Erysimum sp. nov. (Gouraya), 
Table 3. Selected trigger species present at Algerian IPAs

\begin{tabular}{|c|c|}
\hline Selected trigger species & IPA \\
\hline Erica numidica, Genista aspalathoides, Odontites fradini, Odontites triboutii, Rumex algeriensis, Vulpia obtusa & El Kala 1 \\
\hline Odontites triboutii, Odontites ciliata, Scrofularia tenuipes, Scutellaria columnae, Silene chouletii & El Kala 2 \\
\hline Brassica "numidica", Matthiola "numidica", Satureja hispidula, Scrofularia tenuipes, Silene rosulata & Peninsula of Edough \\
\hline Carduus numidicus, Dactylorhiza elata & Guerbes \\
\hline Carduus numidicus, Genista vepres, Limonium spathulatum, Moehringia stellarioides, Pinus renoui, Quercus afares & Collo peninsula \\
\hline Hieracium faurelianum, Hedysarum perralderianum, Linaria decipiens & Belezma \\
\hline $\begin{array}{l}\text { Campanula aurasiaca, Chrysanthemum reboudianum, Galium numidicum, Hieracium peyrimhoffii, Romulea vaillantii, } \\
\text { Eruca Ioncholoma, Linaria decipiens }\end{array}$ & Djebel Chelia \\
\hline $\begin{array}{l}\text { Campanula numidica, Crepis clausonis, Erodium choulettianum, Euphorbia hieroglyphica, Ophrys pallida, Silene } \\
\text { cirtensis, Sinapis aristidis }\end{array}$ & Djebel Ouahch \\
\hline $\begin{array}{l}\text { Abies numidica, Arabis doumetii, Adenocarpus "barbarus", Epimedium perralderianum, Hieracium ernestii, Moehringia } \\
\text { stellaroides, Saxifraga numidica, Silene reverchonii }\end{array}$ & Babor \\
\hline $\begin{array}{l}\text { Digitalis atlantica, Epimedium perralderianum, Erodium battandieranum, Moehringia stellaroides, Pedicularis numidica, } \\
\text { Quercus afares, Satureja pomelii, Saxifraga baborensis }\end{array}$ & Taza \\
\hline $\begin{array}{l}\text { Bupleurum plantagineum, Erysimum sp. nov., Genista salditana, Genista vepres, Hypochoeris saldensis, Pancratium } \\
\text { "saldense", Silene sessionis }\end{array}$ & Gouraya \\
\hline Cephalaria mauretanica, Genista filiramea, Genista vepres, Isoetes perralderiana, Quercus afares, Silene chouletii & Akfadou \\
\hline $\begin{array}{l}\text { Arabis doumetii, Bunium chaberti, Cephalaria mauretanica, Genista filiramea, Pinus "mauretanica", Rindera gymnandra, } \\
\text { Romulea battandieri, Romulea penzigii, Scrofularia tenuipes }\end{array}$ & Djurdjura \\
\hline Polygala munbyana & Mont Chenoua \\
\hline Limonium letourneuxii, Saxifraga "integrifolia", Scabiosa cartenniana & Cap Ténès \\
\hline Cephalaria mauretanica, Orchis "teschneriana", Genista sarotes & Zaccar \\
\hline Adenocarpus umbellatus, Bellevalia pomelii, Brassica spinescens, Silene auriculifolia, Teucrium mauritanicum & Oran's hills \\
\hline Asteriscus "sericeus", Brassica spinescens, Sonchus "amicus", Spergularia pycnorrhiza & Habibas Islands \\
\hline Hammatolobium kremerianum, Limonium asparagoides, Orobanche leptantha, Teucrium mauritanicum & Traras Mountains \\
\hline Carlina atlantica, Eruca setulosa, Filago pomelii, Galium bourgaeanum, Linaria burceziana & Ghar Rouban \\
\hline
\end{tabular}

Nymphoides peltata (Guerbès), Sixalix farinosa (El Kala 1), Seseli praecox (Edough peninsula), Serapias stenopetala (El Kala 1) and Teucrium maghrebinum (Traras mountains, Oran Hills). It is also important to confirm the real distribution of poorly known species such as Erodium battandieranum (Taza), Isoetes perralderiana, Silene chouletii (Akfadou) and Linaria burceziana (Ghar Rouban).

The identification of trigger species was facilitated by the IPA methodology which has been validated for many Mediterranean countries (IUCN et al. 2010). The majority of these are found at high altitude, on the summits of the northern Algerian mountains. Here, the rate of speciation is high due to the isolation of populations, resulting in a large number of endemic species (Table 3). Trigger species were also identified for sites characterised by their geological and geomorphological distinctiveness, such as the limestone and dolomitic cliffs in the Gouraya IPA and the close proximity of dunes, rocks and small islands in the Oran Hills IPA.

Detailed analyses of these lists highlight several species at the edges of their distributions in northern Africa and which may be threatened on a regional or national level, due a combination of small populations, local pressures (deforestation, habitat fragmentation, drought etc), but not across their whole range. This is the case for Buxus sempervirens, Galium odoratum, Neotia nidus-avis, Populus tremula, Stellaria holostea, Viburnum lantana (Babor), Corydalis solida, Hieracium juranum, Monotropa hypopitys, Ononis aragonensis (Babor, Djurdjura), Juniperus sabina (Djurdjura), Paeonia atlantica (cf. Morocco and Algeria), Laurenbergia tetrandra, Oldenlandia capensis, Polygonum amphibium (El Kala 1), Brassica insularis (Edough peninsula), Sedum stellatum (Collo peninsula). These 'edge of range' populations are potentially important sources of genetic variability, which may, particularly in the case of forest species, provide potential for adaptation to the threat of climate 
change (Regato 2008 and references therein).

The present work has resulted in the identification of potentially threatened species whose conservation status requires formal assessment. Such species reinforce arguments in favour of protection and the urgent conservation of the IPAs in which they occur. Important gaps in knowledge have been highlighted, in particular those relating to taxonomy and the lack of up-to-date field data. It is therefore essential to undertake in situ research in order to better understand the distribution and status of these species. Without this effort, it will be impossible to apply criteria that are compatible with those of KBAs and be confident that the results are comprehensive. Up-to-date data will require considerable time and resources; neither are available in abundance.

A flexible approach to identifying and recognising priority sites for plants using surrogate criteria, supplemented by expert opinion, alongside existing globally standardised criteria, is therefore essential if the most important sites for plant diversity are to receive the conservation attention they deserve. Using 'globally standardised criteria' that can only be applied effectively to taxa from better documented taxonomic groups will introduce taxonomic bias to the lists of KBAs, which is better avoided. This applies both in Algeria and other countries and regions which possess exceptionally diverse floras with considerable local endemism. This is particularly important in floristic hotspots such as the Mediterranean, where plant

\section{Appendix 1. Restricted range endemic species from the 22 IPAs of North Algeria (range limited to less than $5000 \mathrm{~km}^{2}$ )}

1. Adenocarpus barbarus (Maire) "comb. nud." [ [= A. complicatus (L.)

J. Gay var. barbarus Maire]

2. Arabis doumetii Coss.

Borago longifolia Poire

Bunium elatum Batt.

Campanula alata Desf.

Campanula numidica Dur.

Carthamus strictus (Pomel) Batt.

Cephalaria mauritanica Pomel [sensu stricto = subsp. eumauritanica]

9. Cerastium gracile L. Dufour [= C. hirtellum ssp. echinulatum

(Cosson \& Dur.) Maire]

10. Cirsium kirbense Pomel

11. Convolvulus durandoi Pomel

12. Coronopus violaceus (Munby) O. Kuntze

13. Crepis clausonis (Pomel) Batt.

14. Crepis patula Poiret

15. Crepis salzmanii Babcock

16. Cynosurus peltieri Maire

17. Daphne oleoides Maire

18. Daucus reboudii Coss

19. Digitalis atlantica Pomel

20. Elatine brochonii Clavaud

21. Epimedium perralderianum Coss.

22. Erodium pachyrhizum Coss.

23. Eruca loncholoma (Pomel) O. E. Schulz

24. Eruca setulosa Boiss. \& Reuter

25. Festuca algeriensis Trab.

26. Fumaria mairei Pugsley

27. Gagea algeriensis Chab. [sensu stricto = var. algeriensis]

28. Galium bourgaeanum Coss.

29. Genista aspalathoides Lam. [sensu stricto = subsp. euaspalathoides]

30. Genista filiramea Pomel [= G. numidica ssp. filiramea (Pomel) Batt.]

31. Genista vepres Pomel

32. Hammatolobium kremerianum (Coss.) C. Muell [= Tripodion

kremerianum (Cosson) Lassen]

33. Helianthemum cinereum (Cav.) Pers. [sensu stricto = subsp. eucinereum]

34. Hypericum afrum Desf.

35. Jasonia rupestris Pomel

36. Juniperus africana (Maire) $\mathrm{H}$. del Villar $[=J$. thurifera L. var. africana Maire ]

37. Limonium asparagoides (Coss. \& Dur.) Maire

38. Limonium spathulatum (Desf.) Kuntze subsp. spathulatum Q. \& S

39. Linaria decipiens Batt.
40. Lonicera kabylica (Batt.) Rehder

41. Lotus drepanocarpus Dur.

42. Moehringia stellarioides Coss.

43. Odontites fradini Pomel

44. Odontites violacea Pomel

45. Ononis cephalantha Pomel [sensu stricto = var. munbyana Maire]

46. Ononis serotina Pomel [sensu stricto $=$ subsp. eu-serotina]

47. Orchis laeta Steinh. [= O. provincialis Balbis var. laeta (Steinheil)

Maire \& Weiller, O. pauciflora Ten. subsp. Laeta (Steinh.) Kreutz]

48. Oreobliton thesioides Dur. \& Moq.

49. Origanum floribundum Munby

50. Orobanche leptantha Pomel

51. Paeonia atlantica (Coss.) Trabut [= P. corallina Retz subsp. atlantica

(Coss.) Maire, = P. corallina Retz subsp. atlantica (Coss.) Greuter \&

Burdet]

52. Phlomis bovei de Noé

53. Pimpinella battandieri Chabert

54. Pinus renoui $(\mathrm{H}$. del Villar) Gaussen $[=$ P. pinaster Aiton subsp.

renoui (H. del Villar) Maire, P. pinaster Aiton subsp. hamiltonii auct. Alg. non (Ten.)]

55. Ptilostemon rhiphaeus (Pau \& Font Quer) Greuter [= Cirsium

casabonae (L.) DC. subsp. trispinosum (Moench) M.]

56. Quercus afares Pomel

57. Satureja hispidula (Boiss. \& Reuter) M. [= Calamintha hispidula Boiss. \& Reuter]

58. Satureja pomelii Briq. [= Calamintha nervosa Pomel]

59. Scabiosa farinosa Cosson [= Sixalix farinosa (Cosson) Greuter \&

Burdet]

60. Scrofularia tenuipes Coss. \& Dur.

61. Scutellaria columnae All.

62. Sedum multiceps Coss. \& Dur.

63. Senecio gallerandianus Coss. \& Dur.

64. Silene oropediorum Coss.

65. Silene reticulata Desf.

66. Silene rosulata Soyer-Willemet \& Godr.

67. Silene velutinoides Pomel

68. Spergularia tenuifolia Pome

69. Stachys mialhesi De Noé

70. Teucrium maghrebianum Greuter \& Burdet [= T. mauritanicum De

Noé non L.]

71. Thymus dreatensis Batt.

72. Thymus lanceolatus Desf.

73. Tragopogon macrocephalus Pomel $[=T$. porrifolius subsp

macrocephalus (Pomel) Batt.]

74. Urginea anthericoides (Poiret) Steinh. [= U. maritima var.

anthericoides (Poiret) Maire \& Weill.]

* Some taxa are treated here as full species even though they are not yet formally recognized as such, reflecting the relative lack of taxonomic work on the flora of the Maghreb. 
Appendix 2. Site restricted endemic species from the 22 IPAs of North Algeria (range limited to less than $100 \mathrm{~km}^{2}$ )

1. Abies numidica De Lannoy ex Carrière

2. Adenocarpus umbellatus Coss.

3. Aethionema thomasianum J. Gay [= A. saxatile (L.) R. Br. subsp. ovalifolium DC.]

4. Allium trichocnemis Gay.

5. Ammiopsis aristidis Coss.

6. Asteriscus sericeus (Maire \& Wilczek) "comb. nud."* [= A. maritimus

var. sericeus Maire \& Wilczek]

7. Astragalus nemorosus Batt. [= A. reinii subsp. nemorosus (Batt.) Maire]

8. Bellevalia pomelii Maire

9. Bellis prostrata Pomel

10. Brassica numidica (Coss.) "comb. nud."* [= B. fruticulosa Cyrillo

subsp. numidica Coss.) Maire]

11. Brassica spinescens Pome

12. Bunium chabertii Batt.

13. Bupleurum plantagineum Desf.

14. Campanula aurasiaca Batt \& Trab. [= Anyseuma rigidum (Willd.)

Grossh. subsp. aurasiacum (Batt. \& Trabut) Damboldt]

15. Carduus numidicus Coss. \& Dur. [ $=$ C. nutans L. subsp. numidicus (Coss. \& Dur.) Arènes]

16. Carlina atlantica Pomel

17. Centaurea papposa (Coss.) Greuter [= Centaurea cineraria L. var. gymnocarpa (Moris) Fiori subvar. papposa (Coss.) Q. \& S.]

18. Centaurea tougourensis Boiss. \& Reut. [sensu stricto $=$ subsp tougourensis]

19. Chrysanthemum reboudianum (Pomel) Quézel \& Santa

20. Cyclamen atlanticum Maire [=Cyclamen repandum subsp.

atlanticum Maire]

21. Dactylorhiza elata (Poiret) Soó [sensu stricto = subsp. elata]

22. Deckera rubiginosa Pomel $[=$ Picris comosa var. rubiginosa (Pomel) Maire]

23. Delphinium emarginatum Presl.

24. Epilobium numidicum Batt.

25. Erica numidica Maire $[=$ Erica cinerea (Maire) Romo \& Boratynski $=$

E. cinerea L. var. numidica Maire]

26. Erodium battandierianum Rouy

27. Erodium choulettianum Coss.

28. Erysimum "sp. nova" [= Cheiranthus cheiri auct. Alg., non L.]

29. Euphorbia hieroglyphica Coss. \& Dur.

30. Filago pomelii Batt. \& Trab.

31. Galium numidicum Pomel

32. Genista salditana Pomel [= G. ferox var salditana (Pomel) Batt.]

33. Genista sarotes Pomel [= G. numidica subsp. sarotes (Pomel) Batt.

34. Hedysarum perralderianum Coss

35. Heracleum algeriense Coss. $[=H$. spondylium $\mathrm{L}$. var aurasiacum

Maire, $=H$. spondylium $\mathrm{L}$. subsp. algeriense (Coss.) Dobignard]

36. Hieracium ernestii Maire

37. Hieracium faurelianum Maire

38. Hieracium peyrimhoffii Maire

39. Hypochaeris saldensis Batt.

40. Isoetes perralderiana Milde [= I. perralderiana Dur. \& Let., = I. velata

A. Br. subsp. perralderiana (Dur. \& Let.) Trab.]

diversity is the overwhelming reason for its status as a 'global biodiversity hotspot'.

\section{REFERENCES}

Anderson, S. (2002). Identifying Important Plant Areas. A site selection manual for Europe and abasisfor developing guidelines for other regions of the world. Plantlife International.

Battandier, J.A. (1888-1890). Flore d'Algérie : Ancienne flore d'Alger transformée... (Dicotylédones). Adolphe Jourdan éditeurs. Alger, 825 pages + appendice I-XXIX.

Battandier J.A. \& L.C. Trabut (1895). Flore de l'Algérie, contenant la description de toutes les plantes signalées
41. Limonium battandieri Greuter \& Burdet

42. Limonium cyrtostachyum (Girard) Brullo [= L. minutiflorum auct.

alg., non Guss.]

43. Limonium letourneuxii (Batt.) Greuter \& Burdet [= Statice letourneuxii Batt.]

44. Linaria burceziana Maire

45. Maresia malcolmioides (Coss. Et Dur.) Pomel

46. Matthiola numidica (Coss.) "comb. nud."* $[=$ M. sinuata (L.) R. Br var. numidica Coss.]

47. Nasturtium munbyanum Boiss. \& Reut. [= Sisymbrella aspera

subsp. munbyana (Boiss. \& Reuter) Greuter \& Burdet]

48. Odontites ciliatus Pomel [= O. purpurea (Desf.) G. Don fil. subp.

ciliata (Pomel) Quézel \& Santa]

49. Odontites discolor Pomel

50. Odontites reboudii Pomel [= O. lutea Clairv. subp. reboudii (Pomel) Quézel \& Santa]

51. Odontites triboutii Gren. \& Paill. = O. luteus Clairv. subsp. triboutii (Gren \& Paill.) Quézel \& Santa]

52. Ophrys pectus Mutel [= O. pallida Raf.]

53. Orchis teschneriana B. \& H. Baumann "comb. nud."* [= O. spitzelii

ssp. teschneriana B. \& H. Baumann, = O. patens var atlantica Desf.]

54. Pancratium saldense (Batt.) * [= P. foetidum var. saldense Batt. ]

55. Pedicularis numidica Pomel

56. Pinus mauretanica (Maire \& Peyerimh.) "comb. nud."* [= $P$. clusiana

Clemente subsp. mauretanica (Maire \& Peyerimh.) Schv. $=P$. nigra

Arnold subsp mauretanica (Maire \& Peyerimh.) Farjon]

57. Polygala munbyana Boiss.

58. Rindera gymnandra (Coss.) Gurka = Mattia gymnadra Coss

59. Romulea battandieri Beguinot

60. Romulea penzigii Beguinot

61. Romulea vaillantii Quéze

62. Rumex algeriensis Barr. \& Murb.

63. Saxifraga "integrifolia (Pons \& Quézel)" non Hook., comb. nud. et illeg. * [= S. globulifera var. integrifolia Pons \& Quézel]

64. Saxifraga baborensis Batt. [= S. cymbalaria var. atlantica Batt.]

65. Saxifraga numidica Maire

66. Scabiosa cartenniana Pons \& Quézel [= Sixalix cartenniana (Pons \& Quézel) Greuter \& Burdet]

67. Serapias stenopetala Maire \& Stephenson

68. Silene auriculifolia Pomel [= S. mollissima (L.) Pers. subsp.

auriculifolia (Pomel) Maire]

69. Silene choulettii Coss.

70. Silene cirtensis Pomel

71. Silene reverchonii Batt.

72. Silene sessionis Batt.

73. Sinapis aristidis Pomel [= S. pubescens L. subsp. aristidis (Pomel) Maire \& Weill.]

74. Solenopsis bicolor (Boiss. \& Reuter) Greuter \& Burdet

75. Sonchus amicus (Faure, Maire \& Wilczek) "comb. nud."* [= S.

tenerrimus var. amicus Faure, Maire \& Wilczek]

76. Spergularia pycnorrhiza (Maire) P. Monnier

77. Taraxacum microcephalum Pomel

78. Vulpia obtusa Trab. 
Appendix 3. List of species based on IUCN threat categories for the 22 Algerian IPAs

\begin{tabular}{|c|c|c|}
\hline $\begin{array}{l}\text { IUCN Red List } \\
\text { categories }\end{array}$ & Species included in the IUCN 1997 and 2010 Red lists & $\begin{array}{l}\text { Total } \\
\text { Number } \\
\text { of species }\end{array}$ \\
\hline $\begin{array}{l}\text { Critically } \\
\text { Endangered }\end{array}$ & Epilobium numidicum (EI Kala 1, El Kala 2), Serapias stenopetala (EI Kala 1) & 2 \\
\hline Endangered & $\begin{array}{l}\text { Abies numidica (Babor), Adenocarpus umbellatus (Oran's hills), Allium trichocnemis (Gouraya), Digitalis } \\
\text { atlantica (Taza), Epimedium perralderianum (Taza, Babor), Galium numidicum (Djebel Chelia), Odontites } \\
\text { discolor (EI Kala 2), Pedicularis numidica (Taza), Rumex algeriensis (El Kala 1), Silene sessionis (Gouraya), } \\
\text { Vulpia obtusa (El Kala 1) }\end{array}$ & 11 \\
\hline Vulnerable & $\begin{array}{l}\text { Bellevalia pomelii (Oran's hills), Brassica spinescens (Habiba's Islands, Oran's hills), Bunium crassifolium (El } \\
\text { Kala 1), Maresia malcomioides (El Kala 1), Polygonum amphibium (EI Kala 1), Satureja hispidula (Edough } \\
\text { peninsula, El Kala 2), Silene reverchoni (Babor), Nasturtium munbyanum (Djebel Chelia, Ghar-Rouban), } \\
\text { Teucrium kabylicum (Akfadou, Taza, Babor, Djurdjura, El Kala 2), Thymus dreatensis (Babor) }\end{array}$ & 10 \\
\hline $\begin{array}{l}\text { Rare / Near } \\
\text { threatened }\end{array}$ & $\begin{array}{l}\text { Ammiopsis aristidis (El Kala 1), Arabis doumetii (Babor, Djurdjura), Bellis prostrata (El Kala 1, Guerbes), } \\
\text { Bunium chaberti (Djurdjura), Bupleurum plantagineum (Gouraya), Campanula alata (Akfadou, Babor, } \\
\text { Djurdjura), Carum montanum (Akfadou, Babor, Belezma, Djurdjura), Cirsium kirbense (Chréa, Djurdjura), } \\
\text { Elatine brochonii (El Kala 1), Erodium battandieranum (Babor, Taza), Hedysarum perralderianum (Belezma), } \\
\text { Hypericum afrum (Akfadou, El Kala 1, Guerbes), Hypochoeris saldensis (Gouraya), Laurentia bicolor (El Kala } \\
\text { 1), Limonium letourneuxii (Cap Ténès), Linaria decipiens (Chelia, Belezma, Djurdjura), Lonicera kabylica } \\
\text { (Babor, Djurdjura), Lotus drepanocarpus, (Edough peninsula) Moehringia stellaroides (Babor, Taza, Collo } \\
\text { peninsula), Odontites fradini (Djurdjura, El Kala 1, El Kala 2, Taza), Oreobliton thesioides (Djebel Chelia, } \\
\text { Djebel Ouahch, Edough peninsula), Origanum floribundum (Chréa, Djurdjura, Theniet El Had), Phlomis } \\
\text { bovei (Akfadou, Babor), Pimpinella battandieri (Babor, Djurdjura), Rindera gymnandra (Djurdjura), Romulea } \\
\text { battandieri (Djurdjura), Romulea penzigii (Djurdjura), Romulea vaillantii (Djebel Chelia), Saxifraga numidica } \\
\text { (Babor), Senecio gallerandianus (Babor, Djebel Chelia, Djurdjura, Theniet El Had), Scabiosa cartenniana } \\
\text { (Cap Ténès), Scabiosa farinosa (El Kala 1), Scrophularia tenuipes (Edough peninsula, Djurdjura, El Kala 2), } \\
\text { Silene reticulata (Chréa, Theniet El Had, Djurdjura), Solenopsis bicolor (El Kala 1, Guerbes), Spergularia } \\
\text { pycnorrhiza (Habibas islands), Stachys mialhesi (Djurdjura), Teucrium atratum (Babor, El Kala 2). }\end{array}$ & 38 \\
\hline Data Deficient & $\begin{array}{l}\text { Campanula aurasiaca (Djebel Chelia), Limonium battandieri (Oran's hills, Traras ) Specularia juliani (Theniet } \\
\text { El Had) }\end{array}$ & 3 \\
\hline
\end{tabular}

Orchideen 37(2): 291-401.

Dobignard, A. \& C. Chatelain (2010-12). Index synonymique et bibliographique de la flore d'Afrique du Nord. Vol.1 Monocotyledonae (2010), Vols. 2-3 (2011), Vols. 4-5 in prep. Consultable sur http://www.ville-ge.ch/musinfo/bd/ cjb/africa/

Emberger, L. (1955). Une classification biogéographique des climats. Naturalia Monspeliensia: Série Botanique 7: 3-42.

Garcia, N., A. Cuttelod \& D.A. Malak (2010). The Status and Distribution of Freshwater Biodiversity in Northern Africa. The IUCN Red List of threatened Species regional Assessment, 141pp.

IUCN, Plantlife International \& World Wildlife Fund (2010). Key Biodiversity Areas for Plants in the Mediterranean: Important Plant Areas, Important Forest Areas and threatened species Unpublished workshop report.

Langhammer, P.F., M.I. Bakarr, L.A. Bennun, T.M. Brooks, R.P. Clay, W. Darwall, N. De Silva, G.J. Edgar, G. Eken, L.D.C. Fishpool, G.A.B. Fonseca, M.N. da Foster, D.H. Knox, P. Matiku, E.A. Radford, A.S.L. Rodrigues, P. Salaman, W. Sechrest \& A.W. Tordoff (2007). Identification and Gap Analysis of Key Biodiversity Areas: Targets for Comprehensive Protected Area Systems. IUCN World Commission on Protected Areas Best Practice Protected Area Guidelines Series No. 15. IUCN, Gland, Switzerland.

Maire, R. (1952-1987). Flore de l'Afrique du Nord (Maroc, Algérie, Tunisie, Tripolitaine, Cyrénaïque, Sahara).
Lechevalier, Paris, Vol I à XVI.

Médail, F. \& K. Diadéma (2009). Glacial refugia influence plant diversity patterns in the Mediterranean Basin. $J$. Biogeogr. 36: 1333-1345.

Médail, F. \& P. Quézel (1997). Hot-spots analysis for conservation of plant biodiversity in the Mediterranean basin. Annals of the Missouri Botanical Garden 84: 112127.

Medjahdi, B., M.I. Tattou, Dj. Barkat \& Kh. Benabdeli (2009). La flore vasculaire des Monts des Trara (NordOuest algérien). Acta Botanica Malacitana 34: 57-75.

Ouarmim, S. \& C. Dubset (2008). Etude écologique, morphologique et systématique de la giroflée (Erysimum sect. Cheiranthus) du Parc National de Gouraya (Bejaia, Algérie). Master 1ère année "Sciences de l'Environnement Terrestre", U. Paul Cézanne (Aix-Marseille 3) / U. Abderrahmane Mira (Bejaia, Algérie), 26pp.

Quézel, P. \& S. Santa (1962-1963). Nouvelle Flore de l'Algérie et des régions désertiques méridionales. Ed. C.N.R.S., Paris, Tomes I \& II, 1170pp.

Plantlife International (2004). Identifying and Protecting The World's Most Important Plant Areas. A Guide to Implementing Target 5 of The Global Strategy for Plant Conservation. Plantlife, Salisbury, UK, 8pp.

Radford, E.A., G. Catullo \& B. de Montmollin (2011). Important Plant Areas of the south and east Mediterranean region: priority sites for conservation. IUCN Malaga

Regato, P. (2001). The Mediterranean Forests, a New Conservation Strategy. WWF-MedPO Ed, Rome. 
Appendix 4. Occurrence of trigger species in the 22 IPAs

\begin{tabular}{|c|c|c|c|}
\hline Species Name & Important Plant Area & Species Name & Important Plant Area \\
\hline 1. Abies numidica & Babor & 45. Epimedium perralderianum & Babor, Taza \\
\hline 2. Adenocarpus barbarus & Babor, Akfadou & 46. Erica numidica & El Kala 1 \\
\hline 3. Adenocarpus umbellatus & Oran Hills & 47. Erodium battandierianum & Babor, Taza \\
\hline 4. Aethionema thomasianum & Djurdjura & 48. Erodium choulettianum & Djebel Ouahch \\
\hline 5. Allium trichocnemis & Gouraya & 49. Erodium pachyrhizum & El Kala 1 \\
\hline 6. Ammiopsis aristidis & El Kala 1 & 50. Eruca loncholoma & Djebel Chelia \\
\hline 7. Arabis doumetii & Babor, Djurdjura & 51. Eruca setulosa & Ghar Rouban \\
\hline 8. Asteriscus sericeus & Habibas Islands & 52. Erysimum "sp. nova" & Gouraya \\
\hline 9. Astragalus nemorosus & Theniet El Had & 53. Euphorbia hieroglyphica & Djebel Ouahch \\
\hline 10. Bellevalia pomelii & Oran Hills & 54. Festuca algeriensis & Belezma, Djurdjura \\
\hline 11. Bellis prostrata & El Kala 1, Guerbes & 55. Filago pomelii & Ghar Rouban \\
\hline 12. Borago longifolia & El Kala 1, Guerbes & 56. Fumaria mairei & Akfadou \\
\hline 13. Brassica numidica & Edough peninsula & 57. Gagea algeriensis & Chréa \\
\hline 14. Brassica spinescens & Oran Hills, Habibas Islands & 58. Galium bourgaeanum & Ghar Rouban \\
\hline 15. Bunium chabertii & Djurdjura & 59. Galium numidicum & Djebel Chelia \\
\hline 16. Bunium elatum & Belezma & 60. Genista aspalathoides & EL Kala 1 \\
\hline 17. Bupleurum plantagineum & Gouraya, & 61. Genista filiramea & Akfadou, Djurdjura \\
\hline 18. Campanula alata & $\begin{array}{l}\text { El Kala 1, Guerbes, Babor, } \\
\text { Akfadou }\end{array}$ & 62. Genista salditana & Gouraya \\
\hline 19. Campanula aurasiaca & Djebel Chelia & 63. Genista sarotes & Zaccar, Taza \\
\hline 20. Campanula numidica & Djebel Ouahch & 64. Genista vepres & $\begin{array}{l}\text { El Kala 2, Akfadou, Taza, } \\
\text { Djurdjura, }\end{array}$ \\
\hline 21. Carduus numidicus & Guerbes, Collo península & 65. Hammatolobium kremerianum & Traras mountains \\
\hline 22. Carlina atlantica & Ghar Rouban & 66. Hedysarum perralderianum & Belezma \\
\hline 23. Carthamus strictus & Djurdjura & 67. Helianthemum cinereum & Chelia, \\
\hline 24. Centaurea papposa & Edough península & 68. Heracleum algeriense & Chelia \\
\hline 25. Centaurea tougourensis & Belezma & 69. Hieracium ernestii & Babor \\
\hline 26. Cephalaria mauritanica & Zaccar, Akfadou, Djurdjura & 70. Hieracium faurelianum & Belezma \\
\hline 27. Cerastium gracile & Ghar Rouban & 71. Hieracium peyrimhoffii & Djebel Chelia \\
\hline 28. Chrysanthemum reboudianum. & Djebel Chelia & 72. Hypericum afrum & Akfadou, \\
\hline 29. Cirsium kirbense & Djurdjura, Chréa & 73. Hypochaeris saldensis & Gouraya \\
\hline 30. Convolvulus durandoi & El Kala 1, El Kala 2 & 74. Isoetes perralderiana & Akfadou \\
\hline 31. Coronopus violaceus & Chréa & 75. Jasonia rupestris & Ghar Rouban \\
\hline 32. Crepis clausonis & Djebel Ouahch & 76. Juniperus africana & Belezma \\
\hline 33. Crepis patula & Taza & 77. Limonium asparagoides & Traras mountains \\
\hline 34. Crepis salzmanii & Oran Hills, Mont Traras & 78. Limonium battandieri & Oran Hills, Traras mountains \\
\hline 35. Cyclamen atlanticum & Taza & 79. Limonium cyrtostachyum & Cap Ténès \\
\hline 36. Cynosurus peltieri & Akfadou & 80. Limonium letourneuxii & Cap Ténès \\
\hline 37. Dactylorhiza elata & Guerbes & 81. Limonium spathulatum & El Kala 1, Collo peninsula \\
\hline 38. Daphne oleoides & $\begin{array}{l}\text { Babor, Djurdjura, Djebel } \\
\text { Chelia }\end{array}$ & 82. Linaria burceziana & Ghar Rouban \\
\hline 39. Daucus reboudii & $\begin{array}{l}\text { Chelia } \\
\text { Gouraya }\end{array}$ & 83. Linaria decipiens & $\begin{array}{l}\text { Belezma, Djebel Chelia, } \\
\text { Djurdjura }\end{array}$ \\
\hline 40. Deckera rubiginosa & Taza & 84. Lonicera kabylica & Babor, Djurdjura \\
\hline 41. Delphinium emarginatum & El Kala 2 & 85. Lotus drepanocarpus & Edough península \\
\hline 42. Digitalis atlantica & Taza, & 86. Maresia malcolmioides & El Kala 1 \\
\hline 43. Elatine brochonii & El Kala 1, Guerbes & 87. Matthiola sinuata & Edough peninsula \\
\hline 44. Epilobium numidicum & El Kala 1, El Kala 2 & 88. Moehringia stellarioides & Babor, Taza, Collo peninsula \\
\hline
\end{tabular}




\begin{tabular}{|c|c|}
\hline Species Name & Important Plant Area \\
\hline 89. Nasturtium munbyanum & Chelia, Ghar Rouban \\
\hline 90. Odontites ciliatus & El Kala 1, El Kala 2 \\
\hline 91. Odontites discolor & El Kala 2 \\
\hline 92. Odontites fradini & $\begin{array}{l}\text { El Kala 1, El Kala 2, } \\
\text { Djurdjura }\end{array}$ \\
\hline 93. Odontites reboudii & El Kala 2 \\
\hline 94. Odontites triboutii & El Kala 1 El Kala 2 \\
\hline 95. Odontites violacea & Djurdjura, \\
\hline 96. Ononis cephalantha & Chréa, Theniet El Had \\
\hline 97. Ononis serotina & Zaccar \\
\hline 98. Ophrys pectus & El Kala 2, Djebel Ouahch \\
\hline 99. Orchis laeta & Akfadou \\
\hline 100. Orchis teschneriana & Zaccar \\
\hline 101. Oreobliton thesoides & $\begin{array}{l}\text { Djebel Chelia, Djebel } \\
\text { Ouahch, Edough peninsula }\end{array}$ \\
\hline 102. Origanum floribundum & $\begin{array}{l}\text { Djurdjura, Chréa, Theniet } \\
\text { El Had }\end{array}$ \\
\hline 103. Orobanche leptantha & Traras mountains \\
\hline 104. Paeonia atlantica & Babor, Akfadou, Djurdjura \\
\hline 105. Pancratium saldense & Gouraya \\
\hline 106. Pedicularis numidica & Taza \\
\hline 107. Phlomis bovei & Babor, Akfadou \\
\hline 108. Pimpinella battandieri & Babor, Djurdjura \\
\hline 109. Pinus mauretanica & Djurdjura \\
\hline 110. Pinus renoui & Collo península \\
\hline 111. Polygala munbyana & Mont Chenoua \\
\hline 112. Ptilostemon rhiphaeus & Djebel Ouahch, Djurdjura \\
\hline 113. Quercus afares & $\begin{array}{l}\text { Akfadou, Taza, Collo } \\
\text { península }\end{array}$ \\
\hline 114. Rindera gymnandra & Djurdjura \\
\hline 115. Romulea battandieri & Djurdjura \\
\hline 116. Romulea penzigii & Djurdjura \\
\hline 117. Romulea vaillantii & Djebel Chelia \\
\hline 118. Rumex algeriensis & El Kala 1 \\
\hline 119. Satureja hispidula & Edough peninsula \\
\hline 120. Satureja pomelii & Taza \\
\hline
\end{tabular}

\begin{tabular}{|c|c|}
\hline Species Name & Important Plant Area \\
\hline 121. Saxifraga "integrifolia" & Cap Ténès \\
\hline 122. Saxifraga baborensis & Taza \\
\hline 123. Saxifraga numidica & Babor \\
\hline 124. Scabiosa cartenniana & Cap Ténès \\
\hline 125. Scabiosa farinosa & El Kala 1 \\
\hline 126. Scrofularia tenuipes & $\begin{array}{l}\text { El Kala 2, Edough } \\
\text { peninsula, Djurdjura, } \\
\text { Akfadou }\end{array}$ \\
\hline 127. Scutellaria columnae & El Kala 2 \\
\hline 128. Sedum multiceps & Babor, Gouraya \\
\hline 129. Senecio gallerandianus & $\begin{array}{l}\text { Djebel Chelia, Babor, } \\
\text { Djurdjura, Theniet El Had }\end{array}$ \\
\hline 130. Serapias stenopetala & El Kala 1 \\
\hline 131. Silene auriculifolia & Oran Hills \\
\hline 132. Silene choulettii & El Kala 2, Akfadou \\
\hline 133. Silene cirtensis & Djebel Ouahch \\
\hline 134. Silene oropediorum & Chréa, Theniet El Had \\
\hline 135. Silene reticulata & $\begin{array}{l}\text { Djurdjura, Chréa, Theniet } \\
\text { El Had }\end{array}$ \\
\hline 136. Silene reverchonii & Babor \\
\hline 137. Silene rosulata & Edough peninsula \\
\hline 138. Silene sessionis & Gouraya \\
\hline 139. Silene velutinoides & Ghar Rouban \\
\hline 140. Sinapis aristidis & Djebel Ouahch \\
\hline 141. Solenopsis bicolor & El Kala 1, Guerbes \\
\hline 142. Sonchus amicus & Habibas Islands \\
\hline 143. Spergularia pycnorrhiza & Habibas Islands \\
\hline 144. Spergularia tenuifolia & Zaccar \\
\hline 145. Stachys mialhesi & Djurdjura, Mont Chenoua \\
\hline 146. Taraxacum microcephalum & Ghar Rouban \\
\hline 147. Teucrium maghrebianum & Oran Hills, Traras mountains \\
\hline 148. Thymus dreatensis & Babor \\
\hline 149. Thymus lanceolatus & Chréa \\
\hline 150. Tragopogon macrocephalus & $\begin{array}{l}\text { Chréa, Zaccar, Theniet El } \\
\text { Had }\end{array}$ \\
\hline 151. Urginea anthericoides & El Kala 2, Edough peninsula \\
\hline 152. Vulpia obtusa & El Kala 1 \\
\hline
\end{tabular}

Regato, P. (2008). Adapting to Global Climate Change. Mediterranean Forests. (Adaptación al cambio global, Los bosques mediterráneos, Adaptation au changement global, Les forêts méditerranéennes). Malaga, Spain: IUCN Centre for Mediterranean Cooperation. ii $+254 \mathrm{pp}$.

Ricketts, T.H., E. Dinerstein, T. Boucher, T.M. Brooks, S.H.M. Butchart, M. Hoffmann, J.F. Lamoreux, J. Morrison, M. Parr, J.D. Pilgrim, A.S.L. Rodrigues, W. Sechrest, G.E. Wallace, K. Berlin, J. Bielby, N.D. Burgess, D.R. Church, N. Cox, D. Knox, C. Loucks, G.W. Luck, L.L. Master, R. Moore, R. Naidoo, R. Ridgely, G.E. Schatz, G. Shire, H. Strand, W. Wettengel \& E. Wikramanayake

(2005). Pinpointing and preventing imminent extinctions. Proceedings of the National Academy of Sciences of the U.S.A. 102: 18497-18501.

Seltzer, P. (1946). Le climat de l'Algérie. Imp. La Typo-Litho \& J. Carbonel. Alger, 219pp.

Véla, E. \& S. Benhouhou (2007). Evaluation d'un nouveau point-chaud de biodiversité végétale dans le bassin méditerranéen (Afrique du nord). C.R. Biologies 330: 589 605.

Véla, E., S. Telaïlia, L.B. Telaïlia \& G. De Bélair (2012) (in press). Découverte de Sixalix farinosa (Coss.) Greuter \& Burdet (Dipsacaceae) en Algérie. 
Lagascalia, 32pp.

Walter, K.S. \& H.J. Gillett (eds.) 1998. 1997 IUCN Red List of Threatened Plants. IUCN, Gland (CH) \& Cambridge (UK), 862pp.

Yahi, N., S. Benhouhou, E. Véla, G. De Belair \& R. Gharzouli (2011). Algeria, pp. 27-30. In: Radford, E.A., G. Catullo \& B. de Montmollin (eds.). Important Plant Areas of The South and East Mediterranean Region: Priority Sites for Conservation. IUCN Malaga.

French abstract: Une étude a été réalisée en 2010 pour identifier les Zones Importantes pour les Plantes (zones clés pour la biodiversité des plantes) dans le sud et l'est de la région méditerranéenne, afin de prioriser les meilleurs sites pour la conservation des plantes. Cette étude complète un premier travail ayant porté sur l'identification de Zones Importantes pour les Plantes (ZIP) dans la partie septentrionale de l'Algérie. Ces ZIP ont été délimitées pour les sites qui hébergent un certain nombre d'espèces à haute valeur patrimoniale (espèces menacées et/ou localement endémiques ou rares). Des révisions taxonomiques récentes estiment le nombre d'espèces endémiques nationales pour le nord de l'Algérie (à l'exclusion du Sahara) à plus de 300 taxons. Dans la présente étude, les données ont été extraites de la liste globale de 22 ZIP identifiées pour le nord de l'Algérie. Les espèces considérées sont: i) des espèces menacées telles que définies par la liste rouge de I'UICN 1997, ii) les espèces endémiques locales, iii) espèces menacées à l'échelle nationale. Des espèces clés (trigger species) ont été identifiées en combinant les critères d'endémisme et de rareté. Ce sont principalement des endémiques algériennes, mais aussi algéro-marocaines et algéro-tunisiennes. Cent cinquante deux (152) espèces clés à grande valeur écologique ont été identifiées et peuvent être utilisées pour caractériser l'intérêt particulier d'un site, devenant ainsi un outil utile à des fins de conservation. Cette étude a mis en exergue d'importantes lacunes dans les connaissances, en particulier celles relatives à la taxonomie et l'absence de données actualisées de terrain. II apparaît donc urgent d'entreprendre des recherches in situ afin de mieux comprendre la répartition et le statut de ces espèces. L'identification et la reconnaissance des sites prioritaires pour les plantes en utilisant des critères combinés, complétés par des avis d'experts et de critères existants, mondialement normalisés, est une approche flexible. Elle est recommandée pour ces sites à haute valeur patrimoniale qui méritent une attention particulière pour leur conservation.

Keywords: Mots-clés : Espèces endémiques, ZIP, Nord de l'Algérie, espèces clés.
Author Details:

NASSIMA YAHI Lecturer at the University of Sciences and Technology "Houari Boumediene", Algiers, Algeria. Main courses phytoecology, sampling strategies in plant ecology. Research interest phytodynamic, phytoecology, phytosociology of forest ecosystems in the Mediterranean area.

ERROL VELA Lecturer at the University of Montpellier-2, France. Main courses on environmental expertise, impact assessment, field botany. Research interest in phytoecology, systematics, taxonomy and biogeography in the Mediterranean area.

Salima Benhounou Senior lecturer in the botany department at the higher national school of agriculture in Algiers, Algeria. Main courses plant ecology and botany. Research interest plant systematic, phytosociology, phytoecology, Mediterranean and Saharan flora.

RACHID GHARZOULI Lecturer at the University "Ferhat Abbas", Setif, Algeria. Main courses: sampling strategies in plant ecology, urban forestry, bioclimatology. Research interest phytosociology, biogeography, urban ecology. GéRARD DE BELAIR Senior lecturer currently retired from University "Badji Mokhtar", Annaba, Algeria. Main courses plant ecology and botany. Research interest plant systematic, phytoecology and Mediterranean flora.

\section{Author Contribution:}

All the above mentioned authors were involved in writing up the current paper and have contributed with their personal data. It was a real team effort whereby the paper was systematically exchanged between the authors to obtain the current paper.
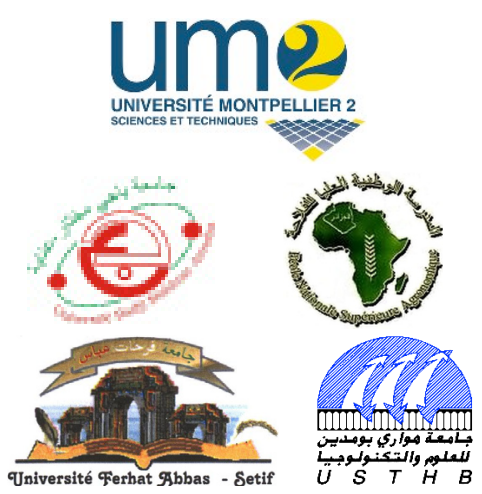